\title{
Nab-paclitaxel for the treatment of breast cancer: efficacy, safety, and approval
}

This article was published in the following Dove Press journal:

OncoTargets and Therapy

I 5 July 201 I

Number of times this article has been viewed

\section{Yutaka Yamamoto' \\ Ichiro Kawano ${ }^{2}$ \\ Hirotaka Iwase'}

'Department of Breast and Endocrine Surgery, Graduate School of Medical

Sciences, Kumamoto University, Kumamoto, Japan; ${ }^{2}$ Department of Surgery, Asahino General Hospital, Kumamoto, Japan
Correspondence: Yutaka Yamamoto Department of Breast and Endocrine Surgery, Graduate School of Medical Sciences, Kumamoto University, I-I-I Honjo, Kumamoto, 860-8556 Kumamoto, Japan

Tel +8I 096373552 I

Fax +8I 0963735525

Email ys-yama@triton.ocn.ne.jp
Abstract: Nanoparticle albumin-bound paclitaxel (nab-paclitaxel) is a novel formulation of paclitaxel that does not require solvents such as polyoxyethylated castor oil and ethanol. Use of these solvents has been associated with toxic response, including hypersensitivity reactions and prolonged sensory neuropathy, as well as a negative impact in relation to the therapeutic index of paclitaxel. nab-paclitaxel displays greater antitumor activity and less toxicity than solvent-base paclitaxel. In a phase I trial of single nab-paclitaxel, the maximum tolerated dose was $300 \mathrm{mg} / \mathrm{m}^{2}$ with the dose limiting toxicities being sensory neuropathy, stomatitis, and superficial keratopathy. In the metastatic setting, a pivotal comparative randomized phase III study demonstrated that nab-paclitaxel (at $260 \mathrm{mg} / \mathrm{m}^{2}$ over 30 minutes infusion without premedication every 3 weeks) mediated a superior objective response rate and prolonged time to progression compared with solvent-based paclitaxel (at $175 \mathrm{mg} / \mathrm{m}^{2}$ over a 3-hour injection with standard premedication). The nab-paclitaxel-treated group showed a higher incidence of sensory neuropathy than the solvent-based paclitaxel group. However, these adverse side effects rapidly resolved after interruption of treatment and dose reduction. Weekly administration of nabpaclitaxel was also more active and displayed less toxicity compared with $100 \mathrm{mg} / \mathrm{m}^{2}$ docetaxel given triweekly. Nab-paclitaxel has already been approved in 42 countries for the treatment of metastatic breast cancer previously treated with anthracycline, based on confirmation of the efficacy and manageable toxicity in the metastatic setting. This review summarizes the most relevant knowledge on nab-paclitaxel for treating breast cancer in terms of clinical usefulness including efficacy and safety of this new agent.

Keywords: nab-paclitaxel, breast cancer, toxicity profile

\section{Introduction}

Breast cancer in women is a major health problem worldwide, with approximately 1,150,000 new cases diagnosed and 410,000 deaths attributed to the disease in $2002 .{ }^{1}$ Breast cancer is a heterogeneous disease in terms of gene expression, morphology, clinical course, and response to treatment. Gene expression profiling divides breast cancer into several subtypes including luminal, human epidermal growth factor receptor 2 (HER2)-enriched, basal-like, and normal-like subtypes. ${ }^{2}$ Lumina A and B subtypes are also classified by expression levels of estrogen receptor (ER)- $\alpha$ and ER- $\alpha$-related gene. Basal-like subtype is almost identical to triple-negative breast cancer which is defined as showing an absence of ER- $\alpha$ and progesterone receptor, and no protein overexpression or gene amplification of HER2. Luminal A subtype has better prognosis than luminal B, HER2-enriched and basal-like subtypes. Luminal and HER2-enriched subtypes have several effective therapeutic targets such as ER for endocrine therapy 
and HER2 for anti-HER2 therapy. Basal-like subtype has no effective therapeutic target at present. The response for cytotoxic agents also different according to tumor subtypes. HER2-enriched and basal-like subtypes are more responsive to chemotherapy than the luminal A subtype. ${ }^{3}$

Chemotherapy for patients with breast cancer is effective in not only reducing recurrence of this disease and improving survival in the adjuvant setting, but also in prolonging survival and improving quality of life in the metastatic setting.

The taxanes, such as paclitaxel and docetaxel, are one of the most active and widely used classes of cytotoxic agents in breast cancer treatment. Taxanes act through binding with tubulin and stabilizing nonfunctional microtubule bundles, leading to subsequent defects in mitotic spindle assembly, chromosome segregation and cell division, resulting in cell death. ${ }^{4,5}$ A meta-analysis showed that the addition of taxane to an anthracycline-based regimen in the adjuvant setting improved the disease-free survival and overall survival (OS) in patients with high-risk early stage breast cancer compared with an anthracycline-based regimen. ${ }^{6}$ Another meta-analysis in the metastatic setting showed that taxane and anthracycline were equivalent in terms of effects on response rate and OS, although the taxanes were significantly less efficacious than anthracyclines in relation to impact on progression-free survival (PFS). ${ }^{7}$ However, the conventionally used taxanes, paclitaxel and docetaxel, have several limitations for clinical use. For example, taxanes are poorly soluble in water due to hydrophobic properties, and they require solvents when used in clinical formulations. However, the use of solvents in the formulation of these therapeutic agents limits their clinical effectiveness, in that these vehicles induce toxic responses, such as hypersensitivity and peripheral neuropathy, and can reduce the extent of drug delivery to tumor. ${ }^{8}$

Nanoparticle albumin-bound paclitaxel (nab-paclitaxel, sold under the trade name Abraxane ${ }^{\circledR}$; Celgene Corporation, Summit, NJ), which is a solvent-free form of paclitaxel, can potentially avoid these limitations. Nab-paclitaxel is widely approved for the treatment of metastatic breast cancer on the basis of results from pivotal trials showing that it has superior antitumor effects and improved tolerability than solventbased paclitaxel. ${ }^{9}$ In this review, we focus on discussing the clinical usefulness, safety, and efficacy of nab-paclitaxel. To achieve our aim, we searched papers on nab-paclitaxel for treating breast cancer electronically, by hand, and through discussion with experts. We mainly used PubMed (from 1970 to 2011) to find published literature.

\section{Development of nab-paclitaxel}

Paclitaxel, a mitotic inhibitor which acts via microtubule stabilization, is isolated from the bark of the Pacific yew tree, Taxus brevifolia, ${ }^{10}$ and is widely used to treat several solid tumor types including breast, lung, and ovarian cancer.

Paclitaxel is highly insoluble in water, with formulation of this agent requiring emulsification with solvents, such as polyoxyethylated castor oil (Cremophor $\mathrm{EL}^{\circledR}$ : CrEL) and ethanol, to allow intravenous administration. ${ }^{11}$ Furthermore, solvent-based paclitaxel must be diluted 5- to 20- fold with normal saline or $5 \%$ dextrose solutions before intravenous administration. ${ }^{12}$

The solvents used in paclitaxel formulation are biologically and pharmacologically active in that they can lead to serious toxicities such as hypersensitivity reaction ${ }^{11}$ and peripheral neuropathy. ${ }^{13,14} \mathrm{CrEL}$ promotes a plasticizer, di(2-ethylhexyl) phthalate (DEHP), which is released from standard intravenous tubing sets containing polyvinyl chloride. Thus the infusional fluid can contain leached DEHP, which subsequently stimulates histamine release and results in hypersensitivity reaction, including anaphylaxis. To offset this adverse response, a special infusion set (containing nonpolyvinyl chloride tubing with an in-line filter) must be used with prolonged infusion, as well as premedication with corticosteroids, antihistamine, and H2-blocker, when administering CrEL-paclitaxel infusion. Despite these precautions, this side effect still occurs at the level of minor reactions, such as flushing and rush, in $40 \%$ of treated patients, with life-threatening metastatic disease in $3 \%$ of treated patients. ${ }^{15}$

CrEL-paclitaxel induces peripheral sensory and motor neuropathy. Indeed, peripheral neuropathy is a dose-limiting factor for CrEL-paclitaxel, with the effect often being prolonged and irreversible. Such irreversible neuropathy is associated axonal degeneration, vesicular degeneration, and demyelination. ${ }^{16,17}$ In addition, CrEL has been shown to have a negative effect in relation to the antitumor properties of paclitaxel. The formation of CrEL micelles in the plasma compartment entraps paclitaxel, resulting in reduced drug clearance, nonlinear pharmacokinetics, and free drug fraction. ${ }^{15,18}$

These findings are strongly associated with the absence of a dose-dependent antitumor response in breast cancer patients treated with paclitaxel. ${ }^{19}$ Several developments have taken place in efforts to avoid the above-mentioned disadvantages of solvent-based taxanes. Nab-paclitaxel, which is CrEL-free, is a key example of such efforts. 


\section{The role of albumin as a drug delivery system and nab-paclitaxel}

Albumin plays an important role in the delivery of hydrophobic molecules to target tissue. Albumin is a natural carrier of endogenous hydrophobic molecules such as vitamins, hormones, and other substances in the human circulation. ${ }^{20,21}$ Albumin binds these substrates reversibly in a noncovalent manner. Albumin is also associated with endothelial transcytosis of protein-bound and unbound plasma components through binding to a $60 \mathrm{kDa}$ cell surface glycoprotein receptor (gp60) on the endothelial cell membrane. gp60 induces caeolin-1, resulting in internalization of the albumin-substrate complex into caveola, transcytotic vesicles, with substrates being subsequently delivered into tumor cells. ${ }^{22-26}$

Nab-paclitaxel is prepared by high-pressure homogenization of paclitaxel in the presence of serum albumin, resulting in a colloidal suspension comprising nanoparticles of $130 \mathrm{~nm}$ on average, which prevent the risk of capillary blockage after intravenous infusion. ${ }^{27,28} \mathrm{Nab}$-paclitaxel consists of a lyophilized powder, which is reconstituted with $20 \mathrm{~mL}$ $0.9 \%$ sodium chloride solution before intravenous infusion. Each single-use vial contains $100 \mathrm{mg}$ of paclitaxel and approximately $900 \mathrm{mg}$ of human albumin. The final colloid solution contains $5 \mathrm{mg} / \mathrm{mL}$ of paclitaxel and approximately $45 \mathrm{mg} / \mathrm{mL}$ of albumin. Based upon in vivo study, it seems that the nab particles disperse into the individual albumin molecules with bound paclitaxel immediately after introduction into aqueous solution, as would occur after injection into the bloodstream. ${ }^{8}$

\section{Preclinical studies}

Using athymic mice bearing human cancer xenografts, Desai et al demonstrated that the antitumor activity and toxicity profile of nab-paclitaxel was better than that of CrELpaclitaxel. ${ }^{27}$ The lethal dose (LD) $)_{50}$ and maximum tolerated dose (MTD) for nab-paclitaxel and CrEL-paclitaxel were 47 and $30 \mathrm{mg} / \mathrm{kg} /$ day and 30 and $13.4 \mathrm{mg} / \mathrm{kg} /$ day, respectively. At equitoxic doses, nab-paclitaxel had significantly better antitumor effects including tumor-free survival, time to tumor recurrence $(P=0.004)$, tumor doubling time $(P=0.0015)$, and tumor volume $(P=0.009)$ compared with CrEL-paclitaxel. At an equal dose of paclitaxel, the level of intratumoral paclitaxel accumulation was higher in nab-paclitaxel-treated mice than those in receipt of CrEL-paclitaxel. The extent of endothelial binding and transcytosis of paclitaxel was significantly greater for nab-paclitaxel than CrEL-paclitaxel, with this difference being completely suppressed by an inhibitor of caveola-mediated transcytosis. CrEL also suppressed paclitaxel binding to endothelial cells and albumin. These findings indicated that nab-paclitaxel mediates greater intratumoral accumulation of paclitaxel and associated increased efficacy compared with CrEL-paclitaxel.

\section{Pharmacokinetic study}

The relevant pharmacokinetic parameters in several studies are shown in Table 1. In a phase I study of nab-paclitaxel administration over 30 minutes every 3 weeks in 19 patients with metastatic melanoma or breast cancer, the MTD was determined to be $300 \mathrm{mg} / \mathrm{m}^{2}{ }^{28}$ The dose-limiting toxicities (DLTs) were sensory neuropathy (3 patients), stomatitis ( 2 patients), and superficial keratopathy (2 patients). No hypersensitivity reaction was observed despite no premedication such as corticosteroids and antihistamines. Nab-paclitaxel also showed linear pharmacokinetics. In more detail, plasma levels of paclitaxel declined in a biphasic manner after intravenous administration of nab-paclitaxel with a rapid first phase representing distribution to the peripheral tissue and the second slower phase representative of drug elimination. Sparreboom et al performed a comparative pharmacokinetics study of nab-paclitaxel $\left(260 \mathrm{mg} / \mathrm{m}^{2}\right.$ given as a 30 -minute infusion $)$ and CrEL-paclitaxel $\left(175 \mathrm{mg} / \mathrm{m}^{2}\right.$ given as a 180 -minute infusion $)$ in patients with metastatic breast, lung, and ovarian cancer. ${ }^{29}$ The maximum concentration of paclitaxel was 6.5 -fold higher for nab-paclitaxel than for CrEL-paclitaxel. The mean area under the curve (AUC) from time zero to infinity and plasma terminal elimination rate for nab-paclitaxel was similar to that observed for CrEL-paclitaxel notwithstanding the differences in administration dose, resulting in similar elimination half-lives for paclitaxel in these two groups. However, the mean apparent total body clearance of the drug from plasma and the apparent volume of distribution during the terminal phase of paclitaxel after administration of nab-paclitaxel were both significantly higher than that seen after administration of CrEL-paclitaxel. This large volume of distribution $\left(664 \mathrm{~L} / \mathrm{m}^{2}\right)$ for nab-paclitaxel suggests extensive extravascular distribution and/or tissue binding of paclitaxel.

Gardner et al also conducted a pharmacokinetic study of nab-paclitaxel $\left(260 \mathrm{mg} / \mathrm{m}^{2}\right.$ given as a 30-minute infusion) compared with CrEL-paclitaxel $\left(175 \mathrm{mg} / \mathrm{m}^{2}\right.$ given as a 180 -minute infusion). ${ }^{30}$ The mean fraction unbound of paclitaxel was significantly higher for nab-paclitaxel than CrEL-paclitaxel $(0.063 \pm 0.021$ vs $0.024 \pm 0.009 ; P<0.001)$, although the total drug exposure was comparable between the two drug formulations. These findings are in agreement with the greater antitumor efficacy of nab-paclitaxel compared with that of CrEL-paclitaxel. 
Table I Pharmacokinetic parameters for nab-paclitaxel and CrEL-paclitaxel

\begin{tabular}{|c|c|c|c|c|c|c|c|c|c|}
\hline Authors & Drug & $\mathbf{n}$ & $\begin{array}{l}\text { Dose } \\
\left(\mathrm{mg} / \mathrm{m}^{2}\right)\end{array}$ & $\begin{array}{l}\text { Infusion } \\
\text { time (min.) }\end{array}$ & $\begin{array}{l}C_{\max } \\
(\mathrm{ng} / \mathrm{mL})\end{array}$ & $\begin{array}{l}\text { AUC }_{\text {inf }} \\
(\mathrm{ng} / \mathrm{h} / \mathrm{mL})\end{array}$ & $t_{1 / 2}(h)$ & $\begin{array}{l}\mathrm{CL} \\
\left(\mathrm{L} / \mathrm{h} / \mathrm{m}^{2}\right)\end{array}$ & $V_{z}\left(L / m^{2}\right)$ \\
\hline \multirow[t]{4}{*}{ Ibrahim et al ${ }^{28}$} & nab-P & 3 & 200 & 30 & 7757 & 9613 & 13.4 & 17.7 & 370 \\
\hline & & & & & $(35 \%)$ & $(20 \%)$ & $(67 \%)$ & $(22 \%)$ & $(23 \%)$ \\
\hline & & 5 & 300 & 30 & 13520 & 17610 & 14.6 & 17.7 & 370 \\
\hline & & & & & $(7 \%)$ & $(21 \%)$ & $(14 \%)$ & $(22 \%)$ & $(23 \%)$ \\
\hline \multirow[t]{4}{*}{ Nyman et $\mathrm{a}^{31}$} & nab-P & 6 & 100 & 30 & 4513 & 4311 & 18.2 & 25.7 & 667 \\
\hline & & & & & $(2002)^{*}$ & $(1557)^{*}$ & $(3.0)^{*}$ & $(8.3)^{*}$ & $(209)^{*}$ \\
\hline & & 3 & 150 & 30 & 8433 & 7107 & 4.8 & 27.4 & 617 \\
\hline & & & & & $(4816)^{*}$ & $(423 I)^{*}$ & $(2.74)^{*}$ & $(16.9)^{*}$ & $(432)^{*}$ \\
\hline \multirow[t]{5}{*}{ Sparreboom et $\mathrm{al}^{29}$} & nab-P & 14 & 260 & 30 & 22969 & 14789 & 21.6 & 21.1 & 664 \\
\hline & & & & & $(113 \%)$ & $(45 \%)$ & $(17.2 \%)$ & $(43.8 \%)$ & $(48 \%)$ \\
\hline & CrEL-P & 12 & 175 & 180 & 3543 & 12603 & 20.5 & 14.8 & 433 \\
\hline & & & & & $(57 \%)$ & $(21 \%)$ & (14.6\%) & (31.8\%) & $(31 \%)$ \\
\hline & & & vs CrEL-I & value & $<0.001$ & 0.524 & 0.479 & 0.048 & 0.040 \\
\hline \multirow[t]{5}{*}{ Gardner et $\mathrm{al}^{30}$} & nab-P & 14 & 260 & 30 & 19556 & 20325 & 20.0 & 13.2 & 375 \\
\hline & & & & & $(36 \%)$ & $(20 \%)$ & (21.3\%) & (17.9\%) & $(22 \%)$ \\
\hline & CrEL-P & 14 & 175 & 180 & 5128 & 20821 & 20.9 & 8.9 & 271 \\
\hline & & & & & $(33 \%)$ & $(26 \%)$ & (21.4\%) & $(25.7 \%)$ & $(6 \mid \%)$ \\
\hline & & & vs CrEL-I & value & $<0.00001$ & 0.72 & 0.53 & 0.00002 & 0.003 \\
\hline \multirow[t]{2}{*}{ Yamada et a ${ }^{32}$} & nab-P & 6 & 260 & 30 & 11635 & 14593 & 19.5 & 18.1 & 510 \\
\hline & & & & & $(13 \%)$ & $(14 \%)$ & (7.9) & (12.9\%) & $(19 \%)$ \\
\hline
\end{tabular}

Notes: The numerical values show mean and coefficient of variation; *standard deviation.

Abbreviations: $\mathrm{n}$, number of patients; $\mathrm{C}_{\max }$, maximum or peak concentration; $\mathrm{AUC}_{\text {inf }}$ area under the whole blood/plasma concentration-time curve from time 0 to time infinity; $\mathrm{CL}$, total body clearance; $\mathrm{V}_{z}$, volume of distribution; nab-P, nab-paclitaxel; CrEL-P, Cremophor $\mathrm{EL}^{\circledR}$-paclitaxel.

Another phase I study of nab-paclitaxel administration (30 minutes once a week for 3 weeks, followed by 1 week of rest) in 39 patients with advanced nonhematologic malignancies was conducted. ${ }^{31}$ In this case, the dose of nab-paclitaxel ranged from 80 to $200 \mathrm{mg} / \mathrm{m}^{2}$. The MTDs for heavily and lightly pretreated patients were $100 \mathrm{mg} / \mathrm{m}^{2}$ and $150 \mathrm{mg} / \mathrm{m}^{2}$, respectively with the observed DLTs being grade 4 neutropenia and grade 3 peripheral neuropathy, respectively. Pharmacokinetics were also linear over the dose range of $80-200 \mathrm{mg} / \mathrm{m}^{2}$.

There was no ethnic difference in the pharmacokinetics of nab-paclitaxel between Westerners and Japanese. ${ }^{32}$

\section{Clinical efficacy in metastatic setting}

Single agent nab-paclitaxel

The tumor responses for single agent nab-paclitaxel in several clinical trials are shown in Table 2(a). Ibrahim et al conducted a phase II trial in 63 patients with metastatic breast cancer, who were treated with $300 \mathrm{mg} / \mathrm{m}^{2}$ nab-paclitaxel over 30 minutes every 3 weeks. ${ }^{33}$ Seventy-six percent of patients received prior chemotherapy, with $38 \%$ of patients having received such treatment in the metastatic setting. Overall response rates were $48 \%$ (95\% CI, 35.3\% to $60.0 \%$ ) while the response rate in patients who had not received prior chemotherapy was $64 \%$ ( $95 \% \mathrm{CI}, 49.0 \%$ to $79.2 \%$ ).
The median times to disease progression and median survival were 26.6 and 63.6 weeks, respectively.

Blum et al performed another phase II study of weekly nab-paclitaxel in patients with metastatic breast cancer, which had been heavily pretreated with taxanes. ${ }^{34}$ In total, 181 patients were treated with either $100 \mathrm{mg} / \mathrm{m}^{2}(\mathrm{n}=106)$ or $125 \mathrm{mg} / \mathrm{m}^{2}(\mathrm{n}=75)$ nab-paclitaxel on days 1,8 , and 15 , followed by 1 week of rest, every 28 days. The response rates of the $100 \mathrm{mg} / \mathrm{m}^{2}$ and $125 \mathrm{mg} / \mathrm{m}^{2}$ cohorts were $14 \%$ and $16 \%$, respectively. The rates of disease control (objective response and stable disease $\geq 16$ weeks) in these two cohorts were $26 \%$ and $37 \%$, respectively. Median PFS and OS were also not significantly different between these two cohorts $\left(100 \mathrm{mg} / \mathrm{m}^{2}\right.$; PFS 3.0 months and OS 9.2 months, $125 \mathrm{mg} / \mathrm{m}^{2}$; PFS 3.5 months and OS 9.1 months). Weekly administration of $100 \mathrm{mg} / \mathrm{m}^{2}$ nab-paclitaxel showed the same antitumor activity as $125 \mathrm{mg} / \mathrm{m}^{2}$, with the benefit of a more favorable toxicity profile in patients with metastatic disease that progressed after previous taxane treatment.

A pivotal international, randomized, open-label phase III trial was conducted to compare the activity and safety of nab-paclitaxel with CrEL-paclitaxel in metastatic breast cancer patients. ${ }^{9}$ Forty-six patients were randomized to nabpaclitaxel $\left(260 \mathrm{mg} / \mathrm{m}^{2}\right.$ over a 30-minute infusion) without premedication or CrEL-paclitaxel $\left(175 \mathrm{mg} / \mathrm{m}^{2}\right.$ over a 3-hour infusion) with standard premedication. Inclusion criteria 


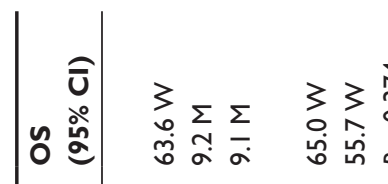

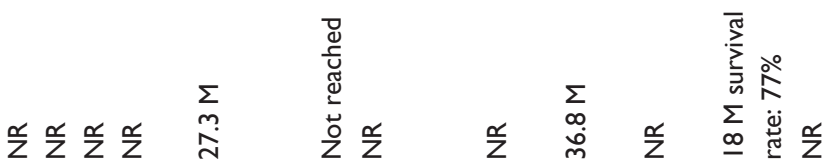

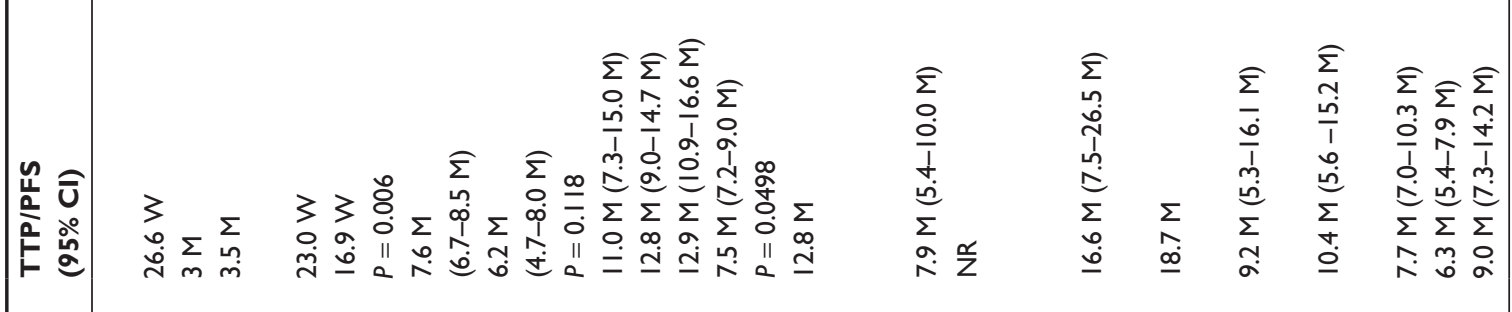

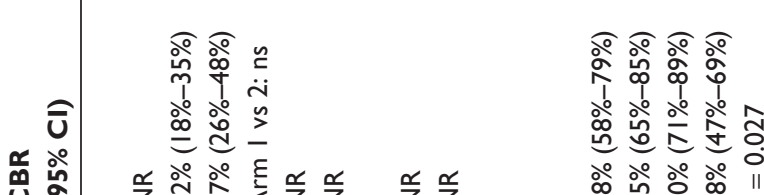

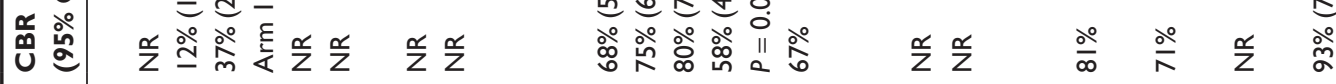

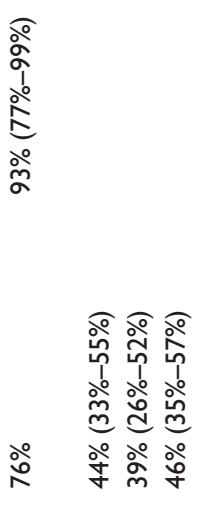

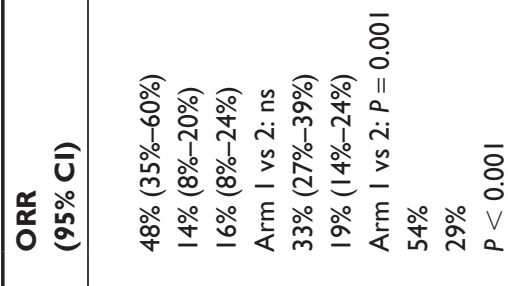

$\overline{8}$

高

$\dot{\mathbf{o}}$

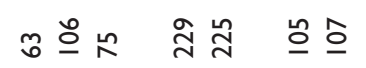

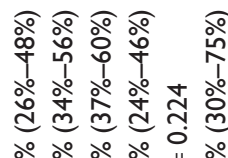

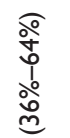

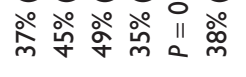

今े ڤ̊ำ

$\stackrel{\circ}{\circ} \stackrel{\circ}{\stackrel{\circ}{Z}}$ (1)

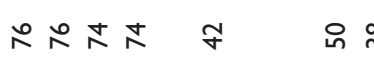

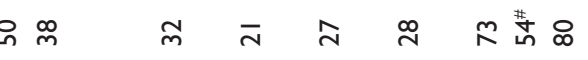

$\frac{\widehat{n}}{\infty} \frac{\widehat{n}}{\infty}$

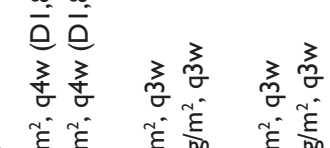

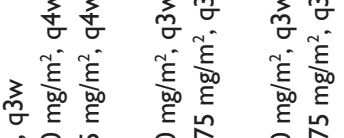

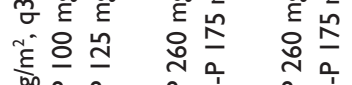

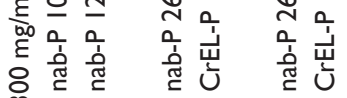

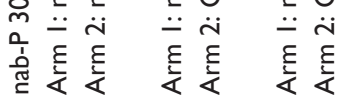

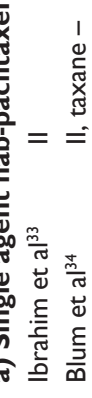

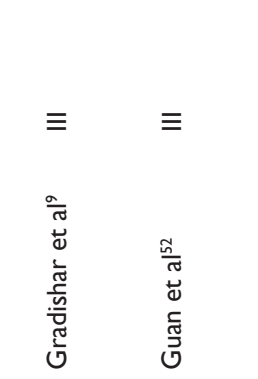

$\stackrel{\oplus}{\underline{\underline{H}}}$
$\stackrel{\underline{\underline{n}}}{\equiv}$

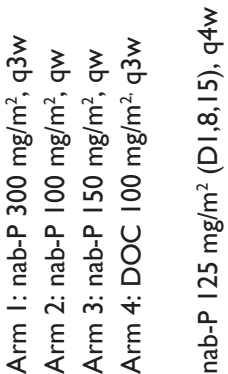

क्ष

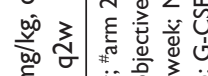

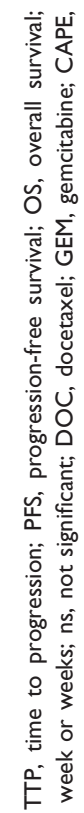

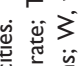

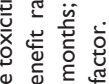

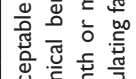

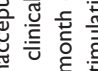

政 $\bar{x}$

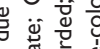

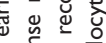

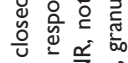

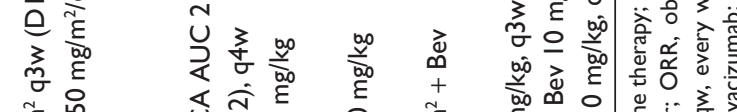

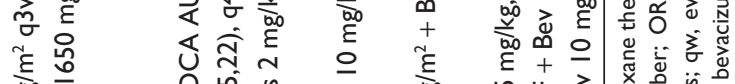

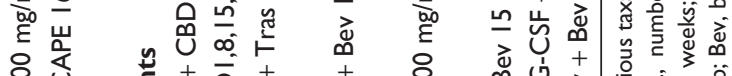

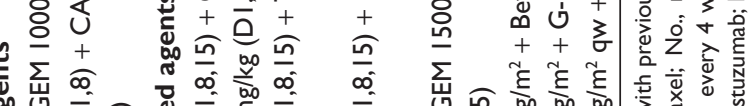

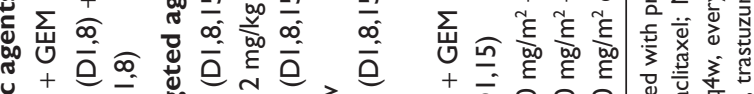

पै

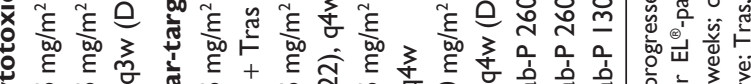

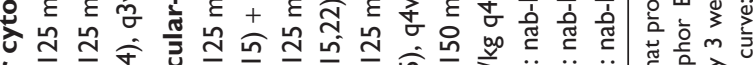

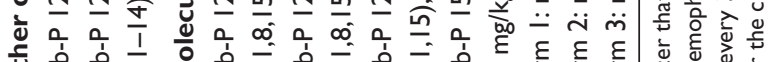

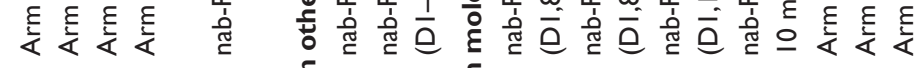

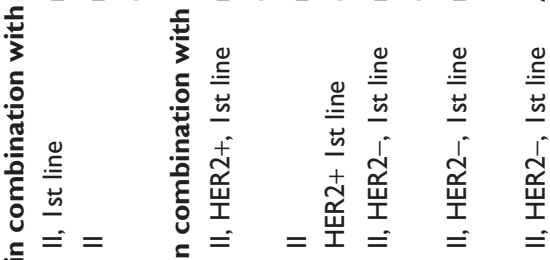

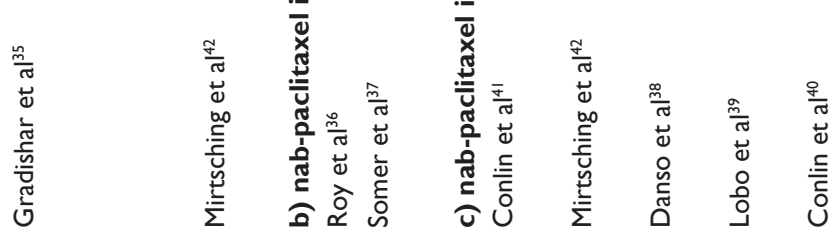

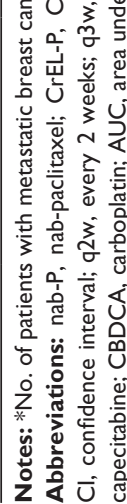


included no receipt of taxane for metastatic disease and no relapse with metastatic disease within 1 year of adjuvant taxane therapy. The objective response rate (ORR) and median time to progression (TTP) were significantly higher in nab-paclitaxel-treated patients than those receiving CrEL-paclitaxel (ORR: nab-paclitaxel 33\% vs CrELpaclitaxel 19\%; $P=0.001$, TTP: nab-paclitaxel 23.0 weeks vs CrEL-paclitaxel 16.9 weeks; hazard ratio $[\mathrm{HR}]=0.75$, $P=0.001)$. Maximum responses occurred by cycle 3 in $91 \%$ of responders in the nab-paclitaxel group and in $81 \%$ of responders in the CrEL-paclitaxel group. The OS in the nab-paclitaxel group was greater than that in CrEL-paclitaxel group (65.0 weeks vs 55.7 weeks, respectively), but this did not reach statistical significance $(P=0.374)$. This trial showed that nab-paclitaxel has superior clinical benefit including greater efficacy and a favorable safety profile without premedication compared with CrEL-paclitaxel.

A randomized phase II study compared nab-paclitaxel administered triweekly and weekly with triweekly docetaxel as first-line treatment for metastatic breast cancer. ${ }^{35}$ Three-hundred and two patients were randomly assigned to $300 \mathrm{mg} / \mathrm{m}^{2}$ nab-paclitaxel every 3 weeks, $100 \mathrm{mg} / \mathrm{m}^{2}$ weekly for 3 out of 4 weeks, $150 \mathrm{mg} / \mathrm{m}^{2}$ weekly for 3 out of 4 weeks, or docetaxel $100 \mathrm{mg} / \mathrm{m}^{2}$ every 3 weeks. Nab-paclitaxel, given as a weekly administration of $150 \mathrm{mg} / \mathrm{m}^{2}$, showed significantly greater PFS than $100 \mathrm{mg} / \mathrm{m}^{2}$ docetaxel given triweekly (12.9 vs 7.5 months, respectively; $P=0.0065$ ). Weekly nab-paclitaxel, regardless of dose, demonstrated a greater ORR than docetaxel (nab-paclitaxel $100 \mathrm{mg} / \mathrm{m}^{2}$ $45 \%, 150 \mathrm{mg} / \mathrm{m}^{2} 49 \%$, docetaxel $35 \%$ ), but this did not reach statistical significance. On the other hand, the disease control rate was significantly greater for patients treated with either dose of weekly nab-paclitaxel compared with docetaxel (100 mg/m² nab-paclitaxel 75\%, $150 \mathrm{mg} / \mathrm{m}^{2} 80 \%$, docetaxel $58 \%, 100 \mathrm{mg} / \mathrm{m}^{2}$ nab-paclitaxel vs docetaxel; $P=0.009$, $150 \mathrm{mg} / \mathrm{m}^{2}$ nab-paclitaxel vs docetaxel; $\left.P=0.017\right)$. No difference between $300 \mathrm{mg} / \mathrm{m}^{2}$ nab-paclitaxel given triweekly, and docetaxel treatment, was observed in terms of PFS and OS. This trial in the first-line metastatic setting showed superior efficacy and safety for weekly, especially $150 \mathrm{mg} / \mathrm{m}^{2}$, nabpaclitaxel compared with triweekly administered docetaxel.

\section{Nab-paclitaxel in combination with cytotoxic agents}

Tumor responses of nab-paclitaxel in combination with cytotoxic agents are listed in Table 2(b). Roy et al reported on a phase II trial of nab-paclitaxel and gemcitabine combination therapy in patients with previously untreated metastatic breast cancer. ${ }^{36}$ Fifty patients received $125 \mathrm{mg} / \mathrm{m}^{2}$ nab-paclitaxel and $1000 \mathrm{mg} / \mathrm{m}^{2}$ gemcitabine on days 1 and 8 every 21 days. The rates of complete response (CR) and partial response (PR) were $8 \%$ and $42 \%$, respectively. The median PFS was 7.9 months (95\% CI 5.4 to 10 months), with PFS and OS at 6 months being $60 \%$ (95\% CI $48 \%$ to $76 \%)$ and $92 \%(95 \%$ CI $85 \%$ to $100 \%$ ), respectively.

A phase II trial of nab-paclitaxel and capecitabine combination therapy in the first-line treatment of metastatic breast cancer has also been reported. ${ }^{37}$ In this case, 50 patients were treated with $125 \mathrm{mg} / \mathrm{m}^{2}$ nab-paclitaxel on days 1,8 , and $1650 \mathrm{mg} / \mathrm{m}^{2}$ capecitabine twice a day on days $1-14$ every 3 weeks. Of the 38 patients available for analysis of response, the ORR was $47.5 \%$ : PR rate was $39.5 \%$, and the CR rate was $8 \%$.

\section{Nab-paclitaxel in combination with molecularly-targeted agents}

Taxane in combination with molecularly targeted therapies, such as trastuzumab and bevacizumab, mediates a greater antitumor effect with acceptable toxicity profiles in the metastatic setting compared with taxane treatment alone. Antitumor effects of nab-paclitaxel in combination with molecular-targeted agents are shown in Table 2(c). The US Oncology Research Network conducted multi-institutional and open-label phase II trials for patients with HER2-negative metastatic breast cancer. ${ }^{38}$ Patients were treated with weekly $125 \mathrm{mg} / \mathrm{m}^{2}$ nab-paclitaxel infusion over 30 minutes on days 1,8 , and 15 , and $10 \mathrm{mg} / \mathrm{kg}$ bevacizumab on day 1 of a 28-day cycle as first-line chemotherapy. Of the 49 patients enrolled, 27 were evaluable for response. The confirmed ORR was $30 \%$ and the proportion of patients with stable disease $>16$ weeks was $22 \%$. The median PFS was 9.2 months (95\% CI, 5.3 to 16.1 months). Lobo et al also reported on a singlecenter and open-label phase II study to examine the efficacy and safety of nab-paclitaxel, in combination with gemcitabine and bevacizumab, in the context of first-line therapy in patients with HER2-negative metastatic breast cancer. ${ }^{39}$ Patients received $150 \mathrm{mg} / \mathrm{m}^{2}$ nab-paclitaxel, $1500 \mathrm{mg} / \mathrm{m}^{2}$ gemcitabine, and $10 \mathrm{mg} / \mathrm{kg}$ bevacizumab on days 1 and 15 of a 28-day cycle. Twenty-nine of the enrolled 30 patients were evaluable for antitumor response. The median PFS was 10.4 months (95\% CI: 5.6-15.2 months), with the ORR and clinical benefit rate being $75.9 \%$ and $93.1 \%$, respectively. Conlin et al conducted an open-label, randomized phase II study of nab-paclitaxel in combination with bevacizumab as first-line chemotherapy for patients with HER2-negative metastatic breast cancer. ${ }^{40}$ Patients were randomly assigned $260 \mathrm{mg} / \mathrm{m}^{2}$ nab-paclitaxel with $15 \mathrm{mg} / \mathrm{kg}$ bevacizumab every 
3 weeks (arm A), $260 \mathrm{mg} / \mathrm{m}^{2}$ nab-paclitaxel and $10 \mathrm{mg} / \mathrm{kg}$ bevacizumab every 2 weeks with figrastim (arm B), or $130 \mathrm{mg} / \mathrm{m}^{2}$ nab-paclitaxel every week with $10 \mathrm{mg} / \mathrm{kg}$ bevacizumab every 2 weeks (arm C). Two-hundred and eight patients were randomized, with 202 patients administered the protocol treatment. There was no difference in ORR between these three groups (arm A: 42\%, arm B: $42 \%$, arm C: $41 \%$ ). The median TTP was longer in arm C (9.2 months) than both arm B (6.4 months) and arm C (7.7 months, overall $P=0.028)$. Arm $B$ was closed early due to an unacceptable toxicity profile, with evidence of significantly more grade $>2$ fatigue (arm A: 39\%, arm B: $57 \%$, arm C: 39\%, $P=0.048$ ) and bone pain (arm A: $10 \%$, arm B: $19 \%$, arm C: $4 \%, P=0.024$ ) as per the protocol-specified stopping rules. Although weekly nab-paclitaxel with bevacizumab for HER2-negative metastatic breast cancer showed the highest therapeutic index, sensory neuropathy was limiting. These data suggest that an adequate weekly regimen for metastatic disease, such as a 3 week on and 1 week rest schedule, should be examined comparatively.

For HER2-positive metastatic breast cancer, Conlin et al also conducted a multicenter phase II study to evaluate the efficacy and safety of weekly nab-paclitaxel in combination with carboplatin and weekly trastuzumab as first-line therapy ${ }^{41}$ In this study, 33 patients were enrolled. Patients received $100 \mathrm{mg} / \mathrm{m}^{2}$ nab-paclitaxel in combination with carboplatin at $\mathrm{AUC}=2$ at days 1,8 , and 15 of a 28-day cycle (in the first set of 13 patients) or at $\mathrm{AUC}=6$ at day 1 every 28 days (in the latter set of 19 patients). Trastuzumab was administered at $2 \mathrm{mg} / \mathrm{kg}$ weekly after a loading dose of $4 \mathrm{mg} / \mathrm{kg}$. The ORR and clinical benefit rates (ORR and SD > 16 weeks) were $62.5 \%$ (95\% CI $45.7 \%$ to $79.3 \%)$ and $81 \%$, respectively. Nab-paclitaxel in combination with carboplatin and trastuzumab is highly active without increasing toxicities in breast cancer patients with HER2positive disease.

Mitrsching et al reported another phase II study of weekly $125 \mathrm{mg} / \mathrm{m}^{2}$ nab-paclitaxel with or without weekly trastuzumab in first-line chemotherapy. ${ }^{42}$ HER2-positive patients received trastuzumab concurrently. Seventy-two patients were enrolled in this study. Of 50 HER2-negative or unknown patients and 22 HER2-positive patients, 42 and 21 patients were evaluable for tumor response. The objective response rates in HER2-negative or HER2positive patients were $38.1 \%$ and $52.4 \%$, respectively. The overall benefits $(\mathrm{CR}+\mathrm{PR}+\mathrm{SD})$ in patients with HER2-negative or HER2-positive patients were $66.7 \%$ and $71.4 \%$, respectively.

\section{In the adjuvant and neoadjuvant setting}

Adjuvant chemotherapy deeply contributes prolongation of survival after standard local treatment. Standard adjuvant regimens are anthracycline-containing regimen and taxane. However, survival benefit form adjuvant chemotherapy is still limited and patients receiving chemotherapy suffer chronic toxicities such as anthracycline-related cardiomyopathy and taxane-induced peripheral neuropathy. Nab-paclitaxel is more effective and less toxic than conventional taxanes, CrEL-paclitaxel and docetaxel, in randomized trials for metastatic breast cancer. Therefore, nab-paclitaxel is likely to be used in an adjuvant chemotherapy regimen. Several adjuvant trials of nab-paclitaxel have been conducted (Table 3).

Yardley et al conducted a pilot study in 62 patients with node positive or high-risk node-negative early-stage breast cancer, who received 4 cycles, at 21-day intervals, of nabpaclitaxel $\left(100 \mathrm{mg} / \mathrm{m}^{2}\right.$ on days 1,8 , and 15$)$ and cyclophosphamide $\left(600 \mathrm{mg} / \mathrm{m}^{2}\right.$ on day 1$) .{ }^{43} \mathrm{HER} 2$ positive patients also received trastuzumab $8 \mathrm{mg} / \mathrm{kg}$ intravenous on cycle 1 day 1 , followed by $6 \mathrm{mg} / \mathrm{kg}$ every 21 days for a total of 52 weeks. Full doses of all agents were administered in $>90 \%$ of cycles. Grade $3 / 4$ neutropenia was observed in $53 \%$ of the patients; however, only one episode of febrile neutropenia was observed in a total of 249 cycles administered. Other grade 3/4 toxicities (fatigue, nausea, vomiting, arthralgia/myalgia, peripheral neuropathy, and edema) were observed in less than $5 \%$ of patients. This combination of weekly nab-paclitaxel and cyclophosphamide with or without trastuzumab is feasible and well tolerated in patients with early stage breast cancer.

Robert et al performed another pilot study of dose-dense doxorubicin plus cyclophosphamide followed by dose-dense nab-paclitaxel in patients with early breast cancer. ${ }^{44}$ In total, 30 patients received 4 cycles of dose-dense doxorubicin $60 \mathrm{mg} / \mathrm{m}^{2}$ plus cyclophosphamide $600 \mathrm{mg} / \mathrm{m}^{2}$ every 2 weeks with pegfilgrastim, followed by dose-dense $260 \mathrm{mg} / \mathrm{m}^{2}$ nabpaclitaxel every 2 weeks (with pegfilgrastim given as needed). Twenty-nine of the 30 patients received nab-paclitaxel. Of the 29 patients, 27 (93.1\%) patients received 4 cycles of nab-paclitaxel. Average and mean dose-intensity of nabpaclitaxel was $120.3 \mathrm{mg} / \mathrm{m}^{2} /$ week and $127.7 \mathrm{mg} / \mathrm{m}^{2} /$ week, respectively. During nab-paclitaxel therapy, 10 (34\%) patients were treated with pegfilgrastim; 27 patients $(90 \%)$ experienced peripheral neuropathy. However, the percentage of patients having $<1$ grade neuropathy at the end of treatment, 2 and 8 months after treatment were 59\%,79\%, and $97 \%$, respectively. Adjuvant dose-dense doxorubicin and cyclophosphamide followed by dose-dense nab-paclitaxel was feasible in patients with early breast cancer. 
Table 3 Adjuvant studies with nab-paclitaxel for breast cancer

\begin{tabular}{|c|c|c|c|c|c|}
\hline Authors & $\begin{array}{l}\text { Study design } \\
\text { and setting }\end{array}$ & Treatment schedule & $\begin{array}{l}\text { No. of } \\
\text { pts. }\end{array}$ & Treatment received & Toxicity \\
\hline $\begin{array}{l}\text { Yardley } \\
\text { et al }{ }^{43}\end{array}$ & $\begin{array}{l}\text { Pilot study } \\
\text { Stage I-III }\end{array}$ & $\begin{array}{l}\text { nab-P I00 mg/m } \\
(D I, 8, I 5)+C P A \\
600 \mathrm{mg} / \mathrm{m}^{2}(\mathrm{DI}) \mathrm{q} 3 \mathrm{w} \times 4 \\
\text { If HER2+, Tras } \\
8 \rightarrow 6 \mathrm{mg} / \mathrm{kg} \mathrm{q} 3 \mathrm{w} \times 52 \mathrm{w}\end{array}$ & 63 & $\begin{array}{l}\text { Discontinued nab-P/CPA: } 2 \% \\
\text { nab-P omission: } 15 \% \\
\text { nab-P reduction: } 6 \%\end{array}$ & $\begin{array}{l}\text { Neutropenia: G3 37\%, G4 } 16 \% \\
\text { Febrile neutropenia: G3 2\% } \\
\text { Fatigue: G3 5\% } \\
\text { Nausea: G3 } 2 \% \\
\text { Arthralgia/myalgias: G 2\% } \\
\text { Peripheral neuropathy: } \\
\text { G2 } 7 \% \text {, G3 2\% }\end{array}$ \\
\hline $\begin{array}{l}\text { Robert } \\
\text { et } \mathrm{al}^{44}\end{array}$ & $\begin{array}{l}\text { Pilot study } \\
\text { Stage I-III }\end{array}$ & $\begin{array}{l}\text { AC q2w } \times 4 \rightarrow \text { nab-P } \\
260 \mathrm{mg} / \mathrm{m}^{2} \mathrm{q} 2 \mathrm{w}+\mathrm{G}-\mathrm{CSF}\end{array}$ & 29 & $\begin{array}{l}\text { Discontinued nab-P: } 7 \% \\
\text { Average elative dose } \\
\text { intensity of nab-P: } 92.5 \%\end{array}$ & $\begin{array}{l}\text { Neutropenia: G3 I0\%, G4 10\% } \\
\text { Febrile neutropenia: G3 0\% } \\
\text { Arthralgia/myalgias: G3 3\% } \\
\text { Peripheral neuropathy: G2 34\%, G3 I4\% }\end{array}$ \\
\hline $\begin{array}{l}\text { McArthur } \\
\text { et } \mathrm{al}^{45}\end{array}$ & $\begin{array}{l}\text { Phase II } \\
\text { Stage I-III } \\
\text { HER2- }\end{array}$ & $\begin{array}{l}\text { AC q2w } \times 4 \rightarrow \text { nab-P } \\
260 \mathrm{mg} / \mathrm{m}^{2} \mathrm{q} 2 \mathrm{w}+ \\
\mathrm{G}-\mathrm{CSF}+\mathrm{Bev} 10 \mathrm{mg} / \mathrm{kg} \\
\mathrm{q} 2 \mathrm{w} \times 8 \rightarrow \mathrm{Bev} \\
15 \mathrm{mg} / \mathrm{kg} \mathrm{q} 3 \mathrm{w} \times 8\end{array}$ & 80 & $\begin{array}{l}\text { Withdraw before completion } \\
\text { of treatment: } 33 \%\end{array}$ & $\begin{array}{l}\text { Febrile neutropenia: G3 4\% } \\
\text { Fatigue: G3 10\% } \\
\text { Peripheral neuropathy: G2 24\%, G3 I4\% } \\
\text { Headache: G3 8\% } \\
\text { Hypertension: G3 I8\%, G4 I\% } \\
\text { Cellulitis/wound-healing complication: } \\
\text { G3 8\% }\end{array}$ \\
\hline
\end{tabular}

Abbreviations: nab-P, nab-paclitaxel; No., number; CPA, cyclophosphamide; Tras, trastuzumab; q3w, every 3 weeks; q2w, every 2 weeks; G, grade; AC, doxorubicin + cyclophosphamide; G-CSF, granulocyte-colony stimulating factor; Bev, bevacizumab; pts, patients.

McArthur et al reported on a feasibility study of bevacizumab plus dose-dense doxorubicin-cyclophosphamide followed by nab-paclitaxel in HER2-negative early-stage breast cancer. ${ }^{45}$ In this study, the authors evaluated the cardiac safety of bevacizumab plus dose-dense doxorubicin and cyclophosphamide followed by nab-paclitaxel. Eighty patients with normal left ventricular ejection fraction (LVEF) were enrolled. Baseline LVEF was 68\%. LVEF at 2, 6, 9, and 18 months after treatment initiation were $68 \%, 64 \%, 63 \%$, and $66 \%$, respectively. One patient developed symptomatic LV dysfunction at month 15 . Common adverse events necessitating treatment discontinuation were hypertension (4\%), wound-healing complication (4\%), and asymptomatic LVEF declines (4\%). Bevacizumab with dose-dense doxorubicin and cyclophosphamide followed by nab-paclitaxel had a low rate of cardiac events.

These adjuvant studies mainly evaluated feasibility and tolerability of nab-paclitaxel in the adjuvant setting. Prospective randomized trials are needed to determine the benefit of incorporating nab-paclitaxel rather than standard taxane formulations, such as solvent-based paclitaxel and docetaxel, in the adjuvant settings.

The purpose of neoadjuvant chemotherapy is to downstage locally advanced cancer to facilitate curative operation, as well as to introduce breast-conserving surgery for operable but large tumors. Several neoadjuvant trials of nab-paclitaxel have been performed for locally advanced and operable breast cancer (Table 4).
Robidoux et al demonstrated the safety and efficacy of nab-paclitaxel, followed by an anthracycline-containing regimen as neoadjuvant chemotherapy, for locally advanced breast cancer patients regardless of hormone receptor or HER2 status. ${ }^{46}$ Sixty-six patients were enrolled, and 65 patients were analyzed in terms of response to this regimen. Patients received $100 \mathrm{mg} / \mathrm{m}^{2}$ of nab-paclitaxel weekly for 12 weeks and FEC $\left(500 \mathrm{mg} / \mathrm{m}^{2} 5\right.$-FU, $100 \mathrm{mg} / \mathrm{m}^{2}$ epirubicine, $500 \mathrm{mg} / \mathrm{m}^{2}$ cyclophosphamide) every 21 days for 4 cycles. Patients with HER2-positive breast cancer received concomitant trastuzumab with nab-paclitaxel and FEC. When patients received trastuzumab, the epirubicin dose was reduced to $75 \mathrm{mg} / \mathrm{m}^{2}$. The pathological complete response (pCR) rate in the breast was $29 \%$ (19 out of 65 patients). For the HER2positive subset, the $\mathrm{pCR}$ rate was $58 \%$ (11 out of 19 patients). This regimen was well tolerated without evidence of cardiac toxicity.

Yardley et al also showed the safety and efficacy of neoadjuvant dose-dense 3-drug combination therapy, nab-paclitaxel, epirubicin, and gemcitabine, together with pegfilgrastim support, for patients with locally advanced breast cancer. ${ }^{47}$ One hundred and twenty-three patients were enrolled, with 109 patients assessed in terms of tumor response. Patients received 6 doses of $2000 \mathrm{mg} / \mathrm{m}^{2}$ gemcitabine, $50 \mathrm{mg} / \mathrm{m}^{2}$ epirubicin, and $175 \mathrm{mg} / \mathrm{m}^{2}$ nab-paclitaxel, administered intravenously on day 1 every 14 days. Following each chemotherapy dose, $6 \mathrm{mg}$ pegfilgrastim was administered subcutaneously on day 2 . The pCR rate was 
Table 4 Neoadjuvant studies with nab-paclitaxel for breast cancer

\begin{tabular}{|c|c|c|c|c|c|}
\hline Authors & $\begin{array}{l}\text { Study design } \\
\text { and setting }\end{array}$ & Treatment schedule & No. of pts. & $\begin{array}{l}\text { PCR } \\
(95 \% \mathrm{Cl})\end{array}$ & Other outcome \\
\hline \multirow[t]{4}{*}{ Paz et al ${ }^{53}$} & Stage II-III & Arm I: TAC $\times 6$ & 15 & $7 \%$ & \\
\hline & & Arm 2: AC q2w $\times 4 \rightarrow$ CBDCA AUC $2+$ nab-P & 14 & $7 \%$ & \\
\hline & & $125 \mathrm{mg} / \mathrm{m}^{2}(\mathrm{DI}, 8,15) \mathrm{q} 4 \mathrm{w} \times 3$ & & & \\
\hline & & $\begin{array}{l}\text { Arm } 3(\text { HER2+): AC q2w } \times 4 \rightarrow \text { CBDCA AUC } 2+ \\
\text { nab-P I } 25 \mathrm{mg} / \mathrm{m}^{2}(\mathrm{DI}, 8,15) \mathrm{q} 4 \mathrm{w} \times 3+\text { tras } q \mathrm{w} \times 12\end{array}$ & 10 & $40 \%$ & \\
\hline \multirow[t]{2}{*}{ Yardley et $\mathrm{al}^{54}$} & Phase II & nab-P $100 \mathrm{mg} / \mathrm{m}^{2}(\mathrm{DI}, 8,15)+\mathrm{CBCDA}$ AUC $6 \mathrm{q} 4 \mathrm{w} \times$ & 20 & $65 \%$ & \\
\hline & Stage II, III & $6+\operatorname{Tras} 4 \rightarrow 2 \mathrm{mg} / \mathrm{kg} / \mathrm{w} \times 2 \mathrm{I}+\operatorname{Bev} 5 \mathrm{mg} / \mathrm{kg} / \mathrm{w} \times 2 \mathrm{I}$ & & & \\
\hline \multirow[t]{3}{*}{ Robidoux et al ${ }^{46}$} & Phase II & nab-P $100 \mathrm{mg} / \mathrm{m}^{2} \times 12 \rightarrow \mathrm{FEC} \mathrm{q} 3 \mathrm{w} \times 4$ & 46 (HER2-) & $17 \%$ & 2-year PFS: 8I\% \\
\hline & Stage IIB-IIIB & If Her2+, concomitant tras was used & 19 (HER2-) & $58 \%$ & $(95 \% \mathrm{Cl}, 70 \%-89 \%)$ \\
\hline & & & & & $\begin{array}{l}\text { 2-years OS: } 95 \% \\
\text { (95\% Cl, 86\%-98\%) }\end{array}$ \\
\hline \multirow[t]{3}{*}{ Yardley et al ${ }^{47}$} & Phase II & nab-P $175 \mathrm{mg} / \mathrm{m}^{2}+$ GEM $2000 \mathrm{mg} / \mathrm{m}^{2}+$ EPI $50 \mathrm{mg} / \mathrm{m}^{2}+$ & 116 & $20 \%$ & ORR: $89 \%$ \\
\hline & Stage I-III & G-CSF $q 2 w \times 6$ & & & 3-year PFS: $48 \%$ \\
\hline & & & & & 3-year OS: $86 \%$ \\
\hline \multirow[t]{2}{*}{ Kaklamani et al ${ }^{48}$} & Stage I-III & nab-P $260 \mathrm{mg} / \mathrm{m}^{2} \mathrm{q} 3 \mathrm{w}+$ lapatinib $1000 \mathrm{mg} /$ day & 30 & $18 \%$ & ORR: $83 \%$ \\
\hline & HER2+ & & & & \\
\hline
\end{tabular}

Abbreviations: AC, doxorubicin $60 \mathrm{mg} / \mathrm{m}^{2}+$ cyclophosphamide $600 \mathrm{mg} / \mathrm{m}^{2} ; \mathrm{TAC}$, docetaxel $75 \mathrm{mg} / \mathrm{m}^{2}+$ doxorubicin $50 \mathrm{mg} / \mathrm{m}^{2}+\mathrm{cyclophosphamide} 500 \mathrm{mg} / \mathrm{m}^{2} ; \mathrm{FEC}, 5 \mathrm{FU}$ $500 \mathrm{mg} / \mathrm{m}^{2}+$ epirubicin $100 \mathrm{mg} / \mathrm{m}^{2}$ + CPA $600 \mathrm{mg} / \mathrm{m}^{2}$; nab-P, nab-paclitaxel; No., number; ORR, objective response rate; PFS, progression-free survival; OS, overall survival; $\mathrm{Cl}$, confidential interval; q3w, every 3 weeks; q4w, every 4 weeks; q2w, every 2 weeks; CBDCA, carboplatin; AUC, area under the curve; Tras, trastuzumab; EPI, epirubicin; G-CSF, granulocyte-colony stimulating factor; pts, patients.

$20 \%$ (23 out of 109 patients), with the estimated 3-year PFS and OS being $48 \%$ and $86 \%$, respectively. Overall, this form of neoadjuvant chemotherapy was well tolerated.

Kaklamani et al conducted an interesting pilot neoadjuvant study in HER2-positive breast cancer which combined nab-paclitaxel and lapatinib, in an effort to avoid use of anthracycline, in patients with HER2-positive cancer. ${ }^{48}$ Thirty patients with stage I-III HER2-positive breast cancer were treated in the neoadjuvant setting with $1000 \mathrm{mg}$ /day lapatinib and $260 \mathrm{mg} / \mathrm{m}^{2}$ nab-paclitaxel every 3 weeks for 4 cycles. The ORR, which was the primary endpoint of this study, and the pCR rate were $82.8 \%$ and $17.9 \%$, respectively. There was no significant drop in the left ventricular ejection fraction. Indeed, this regimen was well tolerated. No predictive factor for response was found in this study.

The results of these neoadjuvant trials are also somewhat promising in the metastatic setting, although the evidence is still quite modest in this respect. Phase III studies comparing nab-paclitaxel-containing regimens with a standard neoadjuvant regimen are needed to determine wider utility in the clinical setting.

\section{Safety}

In a pivotal, randomized phase III trial in the metastatic setting, the toxicity of single agent nab-paclitaxel $\left(260 \mathrm{mg} / \mathrm{m}^{2}\right.$ every 3 weeks) was compared with that mediated by CrELpaclitaxel $\left(175 \mathrm{mg} / \mathrm{m}^{2}\right.$ every 3 weeks) and the data are presented in Table 5. ${ }^{9}$ Treatment compliance of both groups was equally high with 96\% (nab-paclitaxel) or 94\% (CrELpaclitaxel) of patients receiving $90 \%$ of the protocol-specified dose despite a higher dose-intensity of paclitaxel in the nab-paclitaxel group $\left(85.1 \mathrm{mg} / \mathrm{m}^{2} /\right.$ week) than the CrELpaclitaxel group $\left(57.02 \mathrm{mg} / \mathrm{m}^{2} /\right.$ week $)$. Treatment discontinuation, dose reduction and dose delay due to adverse events were also infrequent in both treatment groups. In addition, the safety profile of nab-paclitaxel was comparable to that of CrEL-paclitaxel although there were some differences between the two groups. Consistent with the safety data, no differences in quality of life (QOL) were observed between the two groups.

Grade 4 neutropenia was significantly lower in the nabpaclitaxel group than in the CrEL-paclitaxel group (9\% vs $22 \%$, respectively; $P<0.0001$ ) in a randomized phase III trial. The mean nadir of neutrophils was also significantly higher in the nab-paclitaxel group than that observed in the CrEL-paclitaxel group $\left(1.67 \times 10^{9}\right.$ vs $1.31 \times 10^{9}$, respectively; $P=0.046$ ). These findings suggest that the CrEL vehicle may be responsible for the noted toxicity in patients treated with CrEL-paclitaxel. Febrile neutropenia was uncommon in both treatment groups, as was severe anemia and thrombocytopenia. Hematologic toxicities were dose-dependent and reversible.

Hypersensitivity reactions, such as dyspnea, flushing, chest pain, hypotension, and arrhythmia, can occur during infusion of drugs. Almost all patients treated with nabpaclitaxel received no premedication. On the other hand, 
Table 5 Frequency of important adverse events: nab-paclitaxel $260 \mathrm{mg} / \mathrm{m}^{2}$ versus CrEL-paclitaxel $175 \mathrm{mg} / \mathrm{m}^{2}$

\begin{tabular}{|c|c|c|c|c|}
\hline \multirow[t]{2}{*}{ Adverse events } & \multicolumn{2}{|c|}{ Nab-paclitaxel $(n=229)$} & \multicolumn{2}{|c|}{ CrEL-paclitaxel $(n=225)$} \\
\hline & All grade & $\geq$ Grade 3 & All grade & $\geq$ Grade 3 \\
\hline \multicolumn{5}{|l|}{ Hematologic } \\
\hline Neutropenia & $80 \%$ & $34 \%$ & $82 \%$ & $53 \%$ \\
\hline Thrombocytopenia & $12 \%$ & $<1 \%$ & $15 \%$ & $<1 \%$ \\
\hline Anemia & $47 \%$ & $1 \%$ & $43 \%$ & $<1 \%$ \\
\hline Febrile neutropenia & $2 \%$ & $2 \%$ & $1 \%$ & $1 \%$ \\
\hline Infection & $15 \%$ & $4 \%$ & $14 \%$ & $2 \%$ \\
\hline \multicolumn{5}{|l|}{ Nonhematologic } \\
\hline Hypersensitivity reaction & $4 \%$ & $0 \%$ & $12 \%$ & $2 \%$ \\
\hline Sensory neuropathy & $71 \%$ & $10 \%$ & $56 \%$ & $2 \%$ \\
\hline Myalgia/arthralgia & $44 \%$ & $8 \%$ & $49 \%$ & $4 \%$ \\
\hline Asthenia & $47 \%$ & $8 \%$ & $39 \%$ & $3 \%$ \\
\hline \multicolumn{5}{|l|}{ Gl toxicities } \\
\hline Nausea & $29 \%$ & $3 \%$ & $20 \%$ & $<1 \%$ \\
\hline Vomiting & $16 \%$ & $2 \%$ & $8 \%$ & $<1 \%$ \\
\hline Diarrhea & $25 \%$ & $<1 \%$ & $13 \%$ & $<1 \%$ \\
\hline Mucositis & $15 \%$ & $2 \%$ & $12 \%$ & $<1 \%$ \\
\hline Fluid retention/edema & $10 \%$ & $0 \%$ & $8 \%$ & $<1 \%$ \\
\hline Injection site reaction & $<1 \%$ & & $1 \%$ & \\
\hline
\end{tabular}

Reprinted with permission. (C) 2008 American Society of Clinical Oncology. All rights reserved. Gradishar WJ, Tjulandin S, Davidson N, et al. Phase III trial of nanoparticle albumin-bound paclitaxel compared with polyethylated castor oil-based paclitaxel in women with breast cancer. J Clin Oncol. 2005;23(3I):7794-7803.16

Abbreviations: $\mathrm{CrEL}$, Cremophor $\mathrm{EL}^{\circledR}$; GI, gastrointestinal.

almost all patients treated with CrEL-paclitaxel received premedication with corticosteroids and antihistamines to avoid hypersensitivity reaction. The incidence of this adverse event was low for both groups in the randomized trial. The incidence of severe hypersensitivity reaction was $2 \%$ in the CrEL-paclitaxel group despite their having received standard premedication.

Sensory neuropathy is a key toxic response in patients treated with paclitaxel. As expected, with a higher dose of paclitaxel, the incidence of a severe form of this toxic effect was greater in the nab-paclitaxel group than the CrELpaclitaxel group ( $10 \%$ vs $2 \%$, respectively; $P<0.001)$, as well as the overall incidence of this toxicity $(71 \%$ vs $56 \%$, respectively; $P<0.05$ ), in the pivotal randomized comparative study. Fourteen out of 24 patients with severe sensory neuropathy in the nab-paclitaxel group improved after interruption of treatment in a median 22 days. Nabpaclitaxel-induced peripheral neuropathy could be managed with treatment interruption and dose reduction. The incidence of persistent severe sensory toxicity by 28 days after the first occurrence was equal in both groups. The sensory neuropathy was cumulatively dose dependent and partially reversible.

The incidence of myalgia and arthralgia was of a medium level and almost the same in both groups. These toxicities were usually transient, occurred 2 or 3 days after nabpaclitaxel administration, and resolved within a few days. ${ }^{49}$ Medium-level asthenia was also evident in both groups, albeit with only a low frequency of severe symptoms observed. The incidence of gastrointestinal disorders and fluid retention was also low in both groups.

By comparison, examination of triweekly nab-paclitaxel $\left(300 \mathrm{mg} / \mathrm{m}^{2}\right)$ with weekly nab-paclitaxel $\left(100 \mathrm{mg} / \mathrm{m}^{2}\right.$ or $\left.150 \mathrm{mg} / \mathrm{m}^{2}\right)$ and triweekly docetaxel $\left(100 \mathrm{mg} / \mathrm{m}^{2}\right)$ in a randomized phase II trial (Table 6) showed neutropenia occurring more frequently and in a more severe manner in patients who received docetaxel. In particular, grade 4 neutropenia was significantly higher in patients treated with docetaxel (75\%) compared with patients treated with nab-paclitaxel $100 \mathrm{mg} / \mathrm{m}^{2}$ qw, $150 \mathrm{mg} / \mathrm{m}^{2} \mathrm{qw}$, or $300 \mathrm{mg} / \mathrm{m}^{2}$ q3w $(5 \%, 9 \%, 5 \%$, respectively; $P<0.001$ for all three comparisons).

Consistent with these findings, the incidence of febrile neutropenia was significantly greater in the docetaxel group ( $8 \%$ vs $1 \%$ in each of the nab-paclitaxel groups). Among the three nab-paclitaxel groups, the incidence of all grades and grade 3 sensory neuropathy was higher in those groups with nab-paclitaxel $300 \mathrm{mg} / \mathrm{m}^{2}$ triweekly or $150 \mathrm{mg} / \mathrm{m}^{2}$ weekly compared with $100 \mathrm{mg} / \mathrm{m}^{2}$ weekly. However, the level of severe sensory neuropathy in the nab-paclitaxel groups reduced more rapidly than in the docetaxel group (median time to improvement in grade 3 sensory neuropathy; triweekly 300 $\mathrm{mg} / \mathrm{m}^{2}$ nab-paclitaxel was 22 days, weekly $150 \mathrm{mg} / \mathrm{m}^{2}$ nabpaclitaxel was 19 days, weekly $100 \mathrm{mg} / \mathrm{m}^{2}$ nab-paclitaxel was 22 days, and triweekly docetaxel $100 \mathrm{mg} / \mathrm{m}^{2}$ was 37 days). 
Table 6 Frequency of adverse events in $>25 \%$ of patients in randomized phase II trial: nab-paclitaxel $300 \mathrm{mg} / \mathrm{m}^{2} \mathrm{q} 3 \mathrm{w}$ vs nab-paclitaxel $100 \mathrm{mg} / \mathrm{m}^{2}$ qw vs nab-paclitaxel $150 \mathrm{mg} / \mathrm{m}^{2}$ vs docetaxel $100 \mathrm{mg} / \mathrm{m}^{2} \mathrm{q} 3 \mathrm{w}$

\begin{tabular}{|c|c|c|c|c|}
\hline Adverse events & $\begin{array}{l}\text { Nab-paclitaxel } \\
300 \mathrm{mg} / \mathrm{m}^{2} \\
\text { q3w }(\mathrm{n}=76)\end{array}$ & $\begin{array}{l}\text { Nab-paclitaxel } \\
100 \mathrm{mg} / \mathrm{m}^{2} \\
\text { qw }(\mathrm{n}=76)\end{array}$ & $\begin{array}{l}\text { Nab-paclitaxel } \\
\text { I } 50 \mathrm{mg} / \mathrm{m}^{2} \\
\text { qw }(\mathrm{n}=74)\end{array}$ & $\begin{array}{l}\text { Docetaxel } \\
100 \mathrm{mg} / \mathrm{m}^{2} \\
\text { q3w }(\mathrm{n}=74)\end{array}$ \\
\hline \multicolumn{5}{|l|}{ Neutropenia } \\
\hline All grade & $93 \%$ & $80 \%$ & $91 \%$ & $100 \%$ \\
\hline$>$ Grade 3 & $44 \%$ & $25 \%$ & $44 \%$ & $94 \%$ \\
\hline \multicolumn{5}{|l|}{ Alopecia } \\
\hline All grade & $58 \%$ & $76 \%$ & $64 \%$ & $71 \%$ \\
\hline$>$ Grade 3 & $0 \%$ & $0 \%$ & $0 \%$ & $0 \%$ \\
\hline \multicolumn{5}{|l|}{ Sensory neuropathy } \\
\hline All grade & $73 \%$ & $58 \%$ & $68 \%$ & $61 \%$ \\
\hline$>$ Grade 3 & $17 \%$ & $8 \%$ & $14 \%$ & $12 \%$ \\
\hline \multicolumn{5}{|l|}{ Fatigue } \\
\hline All grade & $36 \%$ & $34 \%$ & $45 \%$ & $55 \%$ \\
\hline$>$ Grade 3 & $5 \%$ & $0 \%$ & $3 \%$ & $19 \%$ \\
\hline \multicolumn{5}{|l|}{ Arthralgia } \\
\hline All grade & $32 \%$ & $19 \%$ & $35 \%$ & $22 \%$ \\
\hline$>$ Grade 3 & $1 \%$ & $0 \%$ & $0 \%$ & $0 \%$ \\
\hline
\end{tabular}

Reprinted with permission. (C) 2008 American Society of Clinical Oncology. All rights reserved. Gradishar WJ, Krasnojon D, Cheporov S, et al. Significantly longer progression-free survival with nab-paclitaxel compared with docetaxel as first-line therapy for metastatic breast cancer. J Clin Oncol. 2009;27(22):36II-36I9.35

Abbreviations: q3w, every 3 weeks; qw, every week.

Fatigue was also more common and severe in the docetaxel group than in the nab-paclitaxel groups. The frequency of arthralgia was higher in patients with nab-paclitaxel given $300 \mathrm{mg} / \mathrm{m}^{2}$ triweekly and nab-paclitaxel $150 \mathrm{mg} / \mathrm{m}^{2}$ given weekly compared with weekly nab-paclitaxel at $100 \mathrm{mg} / \mathrm{m}^{2}$ and docetaxel. The frequency of severe toxicities was less in the weekly $100 \mathrm{mg} / \mathrm{m}^{2}$ nab-paclitaxel compared with triweekly $300 \mathrm{mg} / \mathrm{m}^{2}$ nab-paclitaxel and the weekly $150 \mathrm{mg} / \mathrm{m}^{2}$ nab-paclitaxel. Several studies in the adjuvant setting were conducted to evaluate the tolerability of the nab-paclitaxelcontaining regimen (Table 4). As a pilot study, Yardley et al reported adjuvant weekly nab-paclitaxel at $100 \mathrm{mg} / \mathrm{m}^{2}$ on days 1,8 , and 15 in combination with cyclophosphamide at $600 \mathrm{mg} / \mathrm{m}^{2}$ on day 1 every 3 weeks. If HER 2 positive, patients

Table 7 Comparison between nab-paclitaxel and cremophorbased paclitaxel

\begin{tabular}{|c|c|c|}
\hline & Nab-paclitaxel & CrEL-paclitaxel \\
\hline Premedication & Unnecessary & Necessary \\
\hline In-line filter & Unnecessary & Necessary \\
\hline $\begin{array}{l}\text { Time of } \\
\text { intravenous } \\
\text { infusion }\end{array}$ & 30 minutes & $\begin{array}{l}\text { Weekly: } 60 \text { minutes } \\
\text { Triweekly: } 180 \text { minutes }\end{array}$ \\
\hline $\begin{array}{l}\text { Administration } \\
\text { dose }\end{array}$ & $\begin{array}{l}\text { Weekly: } 100-150 \text { mg/m² } \\
\text { Triweekly: } 260 \mathrm{mg} / \mathrm{m}^{2}\end{array}$ & $\begin{array}{l}\text { Weekly: } 80-100 \text { mg/m² } \\
\text { Triweekly: } 175 \text { mg/m² }\end{array}$ \\
\hline $\begin{array}{l}\text { Administration } \\
\text { for patients with } \\
\text { hypersensitivity } \\
\text { for alcohol }\end{array}$ & Possible & Impossible \\
\hline
\end{tabular}

Abbreviation: CrEL: Cremophor $\mathrm{EL}^{\circledR}$. received triweekly trastuzumab. Sixty-two patients were enrolled in this adjuvant pilot study, which had a low rate of discontinuation and dose reduction for this treatment. ${ }^{47}$

Although dose-dense nab-paclitaxel and bevacizumab combination was not feasible in the metastatic setting, adjuvant dose-dense doxorubicin and cyclophosphamide followed by nab-paclitaxel in combination with bevacizumab showed acceptable toxicity with low cardiac events. ${ }^{45}$ However, the discontinuation rate of this pilot study was not low (33\%). Evaluation of safety and efficacy in the adjuvant setting is too limited. Large, randomized phase III studies to evaluate the efficacy and safety, especially long-term toxicity, of nabpaclitaxel are needed.

\section{Approval of nab-paclitaxel}

Nab-paclitaxel was initially approved by the US Food and Drug Administration on 7th January 2005 and indicated for the treatment of breast cancer after failure of combination chemotherapy for metastatic disease or relapse within 6 months of adjuvant chemotherapy, when prior therapy should have included an anthracycline unless clinically contraindicated. As of March 2011, nab-paclitaxel was approved in 42 countries including EU, Canada, India, and Japan.

\section{Conclusion}

Nab-technology can be used as an effective and novel drug delivery system: nab-paclitaxel (a nanoparticle-based formulation of paclitaxel encapsulated by albumin coating 
instead of (rEL) has increased both the efficacy and safety of paclitaxel. Nab-paclitaxel has also several advantages over CrEL-paclitaxel, such as no need for premedication, special infusion set with in-line filter and alcohol, short infusion time, and high dose administration (Table 7). Nab-paclitaxel can improve the pharmacokinetic parameters of paclitaxel including the facilitation of dose-dependent linear pharmacokinetics, large volume of distribution, and large amount of free paclitaxel, thereby resulting in higher levels of drug delivery to the tumor compared with CrEL-paclitaxel. This is responsible for the increased antitumor effect. Clinical trials have demonstrated that single agent nab-paclitaxel displays high antitumor activity and manageable toxicity for patients with metastatic breast cancer. Phase I studies showed a higher MTD for nab-paclitaxel compared with CrEL-paclitaxel; the MTD of triweekly nab-paclitaxel was $300 \mathrm{mg} / \mathrm{m}^{2}$ and the MTD of weekly nab-paclitaxel in heavily and lightly pretreated patients was $100 \mathrm{mg} / \mathrm{m}^{2}$ and $150 \mathrm{mg} / \mathrm{m}^{2}$, respectively. The DLTs observed were sensory neuropathy, stomatitis, and superficial keratopathy in patients treated with nab-paclitaxel $300 \mathrm{mg} / \mathrm{m}^{2}$ every 3 weeks. The pivotal randomized phase III trial showed that the ORR and time to progression in patients treated with nab-paclitaxel were significantly better than those treated with CrEL-paclitaxel. The OS in patients receiving nab-paclitaxel was apparently greater, albeit with no significant difference, than that seen with patients receiving CrEL-paclitaxel. The safety profile was almost comparable in both groups even though the administration dose of paclitaxel used was higher, without premedication. Sensory neuropathy was significantly greater in the nab-paclitaxel group than in the CrEL-paclitaxel. However, the recovery time for sensory neuropathy was shortened in the nab-paclitaxel group.

The antitumor effect of triweekly nab-paclitaxel $\left(300 \mathrm{mg} / \mathrm{m}^{2}\right)$ was similar to triweekly docetaxel $\left(100 \mathrm{mg} / \mathrm{m}^{2}\right)$. But the tolerability of nab-paclitaxel was favorable compared with that of triweekly docetaxel. Weekly nab-paclitaxel displayed superior antitumor effects and less toxicity compared with triweekly docetaxel. The optimal treatment schedule was not confirmed. However, the weekly regimen in terms of efficacy and tolerability may be better than the triweekly regimen, and CrEL-paclitaxel, for HER2-negative breast cancer based on the results of a randomized phase III trial. ${ }^{50}$ Comparative phase III trials to determine the optimal treatment schedule for nab-paclitaxel are warranted.

In the metastatic setting, nab-paclitaxel has already been used to increase the therapeutic index of paclitaxel compared with CrEL-paclitaxel. For example, in the Ribbon-1 trial, a bevacizumab-focused randomized study comparing paclitaxel alone with paclitaxel in combination with bevacizumab for metastatic breast cancer as first-line chemotherapy, nab-paclitaxel was used for a control arm for standard paclitaxel. ${ }^{51}$ On the other hand, the data relating to nab-paclitaxel treatment in the adjuvant and neoadjuvant settings have been limited even though preliminary results are promising. Therefore, the impact of prolonged recurrence-free and overall survival, as well as long-term toxicity, of a nab-paclitaxel-containing regimen has not been well elucidated. As nab-paclitaxel has higher efficacy and is well tolerated in the metastatic setting, prospective randomized trials of a nab-paclitaxel-containing regimen are urgently required to incorporate nab-paclitaxel rather than standard taxane, solvent-based paclitaxel and docetaxel, into the adjuvant and neoadjuvant settings.

\section{Disclosure}

The authors disclose no conflicts of interest.

\section{References}

1. Cancer IAfRo. Globocan 2002. http://www-dep.iarc.fc/. Accessed June 21, 2011.

2. Sorlie T, Tibshirani R, Parker J, et al. Repeated observation of breast tumor subtypes in independent gene expression data sets. Proc Natl Acad Sci U S A. 2003;100(14):8418-8423.

3. Parker JS, Mullins M, Cheang MC, et al. Supervised risk predictor of breast cancer based on intrinsic subtypes. J Clin Oncol. 2009; 27(8):1160-1167.

4. Schiff PB, Fant J, Horwitz SB. Promotion of microtubule assembly in vitro by taxol. Nature. 1979;277(5698):665-667.

5. Ringel I, Horwitz SB. Studies with RP 56976 (taxotere): a semisynthetic analogue of taxol. J Natl Cancer Inst. 1991;83(4):288-291.

6. De Laurentiis M, Cancello G, D'Agostino D, et al. Taxane-based combinations as adjuvant chemotherapy of early breast cancer: a metaanalysis of randomized trials. J Clin Oncol. 2008;26(1):44-53.

7. Piccart-Gebhart MJ, Burzykowski T, Buyse M, et al. Taxanes alone or in combination with anthracyclines as first-line therapy of patients with metastatic breast cancer. J Clin Oncol. 2008;26(12):1980-1986.

8. Gradishar WJ. Albumin-bound paclitaxel: a next-generation taxane. Expert Opin Pharmacother. 2006;7(8):1041-1053.

9. Gradishar WJ, Tjulandin S, Davidson N, et al. Phase III trial of nanoparticle albumin-bound paclitaxel compared with polyethylated castor oil-based paclitaxel in women with breast cancer. J Clin Oncol. 2005;23(31):7794-7803.

10. Wani MC, Taylor HL, Wall ME, Coggon P, McPhail AT. Plant antitumor agents. VI. The isolation and structure of taxol, a novel antileukemic and antitumor agent from Taxus brevifolia. J Am Chem Soc. 1971; 93(9):2325-2327.

11. Rowinsky EK, Cazenave LA, Donehower RC. Taxol: a novel investigational antimicrotubule agent. J Natl Cancer Inst. 1990;82(15):1247-1259.

12. Miele E, Spinelli GP, Tomao F, Tomao S. Albumin-bound formulation of paclitaxel (Abraxane ABI-007) in the treatment of breast cancer. Int J Nanomedicine. 2009;4:99-105.

13. Windebank AJ, Blexrud MD, de Groen PC. Potential neurotoxicity of the solvent vehicle for cyclosporine. J Pharmacol Exp Ther. 1994;268(2):1051-1056.

14. Authier N, Gillet JP, Fialip J, Eschalier A, Coudore F. Description of a short-term Taxol-induced nociceptive neuropathy in rats. Brain Res. 2000;887(2):239-249. 
15. ten Tije AJ, Verweij J, Loos WJ, Sparreboom A. Pharmacological effects of formulation vehicles: implications for cancer chemotherapy. Clin Pharmacokinet. 2003;42(7):665-685.

16. Windebank AJ. The vehicle for cyclosporine is neurotoxic in vitro. Ann Neurol. 1997;41(4):563-564.

17. Authier N, Gillet JP, Fialip J, Eschalier A, Coudore F. Assessment of neurotoxicity following repeated cremophor/ethanol injections in rats. Neurotox Res. 2001;3(3):301-306.

18. Sparreboom A, van Zuylen L, Brouwer E, et al. Cremophor EL-mediated alteration of paclitaxel distribution in human blood: clinical pharmacokinetic implications. Cancer Res. 1999;59(7):1454-1457.

19. Winer EP, Berry DA, Woolf S, et al. Failure of higher-dose paclitaxel to improve outcome in patients with metastatic breast cancer: cancer and leukemia group B trial 9342. J Clin Oncol. 2004;22(11): 2061-2068.

20. Curry S, Mandelkow H, Brick P, Franks N. Crystal structure of human serum albumin complexed with fatty acid reveals an asymmetric distribution of binding sites. Nat Struct Biol. 1998;5(9):827-835.

21. Herve F, Urien S, Albengres E, Duche JC, Tillement JP. Drug binding in plasma. A summary of recent trends in the study of drug and hormone binding. Clin Pharmacokinet. 1994;26(1):44-58.

22. Carver LA, Schnitzer JE. Caveolae: mining little caves for new cancer targets. Nat Rev Cancer. 2003;3(8):571-581.

23. John TA, Vogel SM, Tiruppathi C, Malik AB, Minshall RD. Quantitative analysis of albumin uptake and transport in the rat microvessel endothelial monolayer. Am J Physiol Lung Cell Mol Physiol. 2003; 284(1):L187-L196.

24. Minshall RD, Sessa WC, Stan RV, Anderson RG, Malik AB. Caveolin regulation of endothelial function. Am J Physiol Lung Cell Mol Physiol. 2003;285(6):L1179-L1183.

25. Tiruppathi C, Song W, Bergenfeldt M, Sass P, Malik AB. Gp60 activation mediates albumin transcytosis in endothelial cells by tyrosine kinasedependent pathway. J Biol Chem. 1997;272(41):25968-25975.

26. Vogel SM, Minshall RD, Pilipovic M, Tiruppathi C, Malik AB. Albumin uptake and transcytosis in endothelial cells in vivo induced by albumin-binding protein. Am J Physiol Lung Cell Mol Physiol. 2001; 281(6):L1512-L1522.

27. Desai N, Trieu V, Yao Z, et al. Increased antitumor activity, intratumor paclitaxel concentrations, and endothelial cell transport of cremophorfree, albumin-bound paclitaxel, ABI-007, compared with cremophorbased paclitaxel. Clin Cancer Res. 2006;12(4):1317-1324.

28. Ibrahim NK, Desai N, Legha S, et al. Phase I and pharmacokinetic study of ABI-007, a Cremophor-free, protein-stabilized, nanoparticle formulation of paclitaxel. Clin Cancer Res. 2002;8(5): 1038-1044.

29. Sparreboom A, Scripture CD, Trieu V, et al. Comparative preclinical and clinical pharmacokinetics of a cremophor-free, nanoparticle albuminbound paclitaxel (ABI-007) and paclitaxel formulated in Cremophor (Taxol). Clin Cancer Res. 2005;11(11):4136-4143.

30. Gardner ER, Dahut WL, Scripture CD, et al. Randomized crossover pharmacokinetic study of solvent-based paclitaxel and nab-paclitaxel. Clin Cancer Res. 2008;14(13):4200-4205.

31. Nyman DW, Campbell KJ, Hersh E, et al. Phase I and pharmacokinetics trial of ABI-007, a novel nanoparticle formulation of paclitaxel in patients with advanced nonhematologic malignancies. J Clin Oncol. 2005;23(31):7785-7793.

32. Yamada K, Yamamoto N, Yamada Y, Mukohara T, Minami H, Tamura T. Phase I and pharmacokinetic study of ABI-007, albuminbound paclitaxel, administered every 3 weeks in Japanese patients with solid tumors. Jpn J Clin Oncol. 2010;40(5):404-411.

33. Ibrahim NK, Samuels B, Page R, et al. Multicenter phase II trial of ABI-007, an albumin-bound paclitaxel, in women with metastatic breast cancer. J Clin Oncol. 2005 Sep 1;23(25):6019-6026.

34. Blum JL, Savin MA, Edelman G, et al. Phase II study of weekly albumin-bound paclitaxel for patients with metastatic breast cancer heavily pretreated with taxanes. Clin Breast Cancer. 2007;7(11): $850-856$.
35. Gradishar WJ, Krasnojon D, Cheporov S, et al. Significantly longer progression-free survival with nab-paclitaxel compared with docetaxel as first-line therapy for metastatic breast cancer. J Clin Oncol. 2009; 27(22):3611-3619.

36. Roy V, LaPlant BR, Gross GG, Bane CL, Palmieri FM. Phase II trial of weekly nab (nanoparticle albumin-bound)-paclitaxel (nab-paclitaxel) (Abraxane) in combination with gemcitabine in patients with metastatic breast cancer (N0531). Ann Oncol. 2009;20(3):449-453.

37. Somer BD, Schwartzberg LS, Arena F, Epperson A, Fu D, Fortner BV. Phase II trial of nab-paclitaxel (nanoparticle albumin-bound paclitaxel $(\mathrm{ABX}))+$ capecitabine $(\mathrm{XEL})$ in first-line treatment of metastatic breast cancer (MBC). Journal of Clinical Oncology, 2007 ASCO Annual Meeting Proceedings Part I. 2007;25(18S):1053.

38. Danso MA, Blum JL, Robert NJ, et al. Phase II trial of weekly nabpaclitaxel in combination with bevacizumab as first-line treatment in metastatic breast cancer. J Clin Oncol. 2008 May 20;(Suppl 26): Abstr 1075.

39. Lobo C, Lopes G, Baez O, et al. Final results of a phase II study of nab-paclitaxel, bevacizumab, and gemcitabine as first-line therapy for patients with HER2-negative metastatic breast cancer. Breast Cancer Res Treat. 2010;123(2):427-435.

40. Conlin AK, Hudis CA, Bach A, et al. Randomized phase II trial of nanoparticle albumin-bound paclitaxel in three dosing schedules with bevacizumab as first-line therapy for HER2-negative metastatic breast cancer (MBC). J Clin Oncol 2009;27(Suppl 15):Abstr 1006.

41. Conlin AK, Seidman AD, Bach A, et al. Phase II trial of weekly nanoparticle albumin-bound paclitaxel with carboplatin and trastuzumab as first-line therapy for women with HER2-overexpressing metastatic breast cancer. Clin Breast Cancer. 2010;10(4):281-287.

42. Mirtsching B, Cosgriff T, Harker G, Keaton M, Chidiac T, Min M. A Phase II study of weekly nanoparticle albumin-bound paclitaxel with or without trastuzumab in metastatic breast cancer. Clin Breast Cancer. 2011;11(2):121-128.

43. Yardley D, Burris H 3rd, Peacock N, et al. A pilot study of adjuvant nanoparticle albumin-bound (nab) paclitaxel and cyclophosphamide, with trastuzumab in HER2-positive patients, in the treatment of early-stage breast cancer. Breast Cancer Res Treat. 2010;123(2): $471-475$.

44. Robert N, Krekow L, Stokoe C, Clawson A, Iglesias J, O’Shaughnessy J. Adjuvant dose-dense doxorubicin plus cyclophosphamide followed by dose-dense nab-paclitaxel is safe in women with early-stage breast cancer: a pilot study. Breast Cancer Res Treat. 2011;125(1): 115-120.

45. McArthur HL, Rugo H, Nulsen B, et al. A feasibility study of bevacizumab plus dose-dense doxorubicin-cyclophosphamide $(\mathrm{AC})$ followed by nanoparticle albumin-bound paclitaxel in early-stage breast cancer. Clin Cancer Res. Feb 24, 2011.

46. Robidoux A, Buzdar AU, Quinaux E, et al. A phase II neoadjuvant trial of sequential nanoparticle albumin-bound paclitaxel followed by 5-fluorouracil/epirubicin/cyclophosphamide in locally advanced breast cancer. Clin Breast Cancer. 2010;10(1):81-86.

47. Yardley DA, Zubkus J, Daniel B, et al. A phase II trial of dose-dense neoadjuvant gemcitabine, epirubicin, and albumin-bound paclitaxel with pegfilgrastim in the treatment of patients with locally advanced breast cancer. Clin Breast Cancer. 2010;10(5):367-372.

48. Kaklamani VG, Siziopikou K, Scholtens D, et al. Pilot neoadjuvant trial in HER2 positive breast cancer with combination of nab-paclitaxel and lapatinib. Breast Cancer Res Treat. Feb 27, 2011.

49. Petrelli F, Borgonovo K, Barni S. Targeted delivery for breast cancer therapy: the history of nanoparticle-albumin-bound paclitaxel. Expert Opin Pharmacother. 2010;11(8):1413-1432.

50. Seidman AD, Berry D, Cirrincione C, et al. Randomized phase III trial of weekly compared with every-3-weeks paclitaxel for metastatic breast cancer, with trastuzumab for all HER-2 overexpressors and random assignment to trastuzumab or not in HER-2 nonoverexpressors: final results of Cancer and Leukemia Group B protocol 9840. J Clin Oncol. 2008;26(10):1642-1649. 
51. Robert NJ, Dieras V, Glaspy J, et al. RIBBON-1: randomized, double-blind, placebo-controlled, phase III trial of chemotherapy with or without bevacizumab for first-line treatment of human epidermal growth factor Receptor 2-negative, locally recurrent or metastatic breast cancer. J Clin Oncol. 2011;29(10):1252-1260.

52. Guan Z, Feng F, Li QL, et al. Randomized study comparing nabpaclitaxel with solvent-based paclitaxel in Chinese patients (pts) with metastatic breast cancer (MBC). Journal of Clinical Oncology, 2007 ASCO Annual Meeting Proceedings Part I. 2007 Jun 20; 25(Suppl 18):1038.
53. Paz IB, Lau S, Garberoglio C, et al. Nab-paclitaxel and carboplatin with or without trastuzumab (trast) as part of neoadjuvant chemotherapy (NCT) in patients (pts) with stage II-III breast cancer (BC). J Clin Oncol. 2008 May 20;(Suppl 26):Abstr 567.

54. Yardley DA, Raefsky E, Castillo R, et al. Results of a multicenter pilot study of weekly nab-paclitaxel, carboplatin with bevacizumab, and trastuzumab as neoadjuvant therapy in HER2+ locally advanced breast cancer with SPARC correlatives. J Clin Oncol. 2009; 27(Suppl 15):Abstr 527.

\section{Publish your work in this journal}

OncoTargets and Therapy is an international, peer-reviewed, open access journal focusing on the pathological basis of all cancers, potential targets for therapy and treatment protocols employed to improve the management of cancer patients. The journal also focuses on the impact of management programs and new therapeutic agents and protocols on

\section{Dovepress}

patient perspectives such as quality of life, adherence and satisfaction. The manuscript management system is completely online and includes a very quick and fair peer-review system, which is all easy to use. Visit http://www.dovepress.com/testimonials.php to read real quotes from published authors. 